\section{Establishment of a Collection of Rosa Species through in Vitro Embryo Culture}

\author{
Denis Lauzer \\ Institut de recherche en biologie végétale, Université de Montréal, 4101, rue \\ Sherbrooke est, Montréal, Que. H1X 2B2, Canada
}

Claire Laberge

Jardin botanique de la Ville de Montréal, 4101, rue Sherbrooke est, Montréal, Que. H1X 2B2, Canada

Additional index words. seeds, dormancy, acclimatization

\begin{abstract}
To update and complete a collection of wild roses in the Montreal Botanical Garden, Canada, in vitro embryo culture was used to propagate several Rosa species that are only available as seeds and difficult to germinate conventionally. Using embryo culture, it was possible to overcome seed dormancy and to rapidly increase the number of species in the collection, and this from a very limited number of seeds obtained from botanical institutions located around the world.
\end{abstract}

The Montreal Botanical Garden possesses a rich collection of more than 100 species of the genus Rosa coming from all over the world. These species are typically available only as seeds. Thus, the growth of the collection is slowed by the difficulty of germinating seeds. To update and increase the number of species in the collection, embryo culture was used to obtain several species of Rosa that could not be germinated conventionally.

Through embryo culture, it is possible to study embryonic development, bypass seed dormancy, test seed viability, and rescue immature hybrid embryos from otherwise incompatible crosses (Hu and Wang, 1986). Embryo culture has been applied to many plant species (Collins and Grosser, 1984). In roses, where the thick pericarp and growth inhibitors in the achene cause dormancy of the seeds, breeders use embryo culture to bypass dormancy and to shorten the breeding cycles (Asen, 1948; Lammerts, 1946; Marchant et al., 1994; Skirvin et al., 1990). In the present work, rose embryo culture was used to develop a collection of typically noncultivated wild species of Rosa.

\section{Materials and Methods}

For all experiments, seeds were stored at $4{ }^{\circ} \mathrm{C}$ upon arrival from contributors. Depending on the date of arrival, seeds were stored from 6 to 12 months before disinfection. Seeds were surface-sterilized for $1 \mathrm{~min}$ in $70 \%$ ethanol, followed by $45 \mathrm{~min}$ in $2.4 \%$ (w/v) sodium hypochlorite $(\mathrm{NaOCl})$ solution with $0.1 \%$ Tween 20 (Fisher Scientific, N.J.), then rinsed three times in sterile water. Seeds were not

Received for publication 15 Aug. 1995. Accepted for publication $27 \mathrm{Feb}$. 1996. The cost of publishing this paper was defrayed in part by the payment of page charges. Under postal regulations, this paper therefore must be hereby marked advertisement solely to indicate this fact.
Germination of $R$. nitida, $R$. acicularis, and $R$. carolina was only possible when the embryo was removed from the seed and cultured in vitro (Table 1). Isolated embryos of $R$. nitida and $R$. acicularis germinated at $100 \%$ and $93 \%$, respectively, while embryos of $R$. carolina germinated at only $60 \%$. The low germination percentage of $R$. carolina embryos may be due to poor seed conservation conditions before arrival at the Montreal Botanical Garden or because fruit were collected before complete maturation. In vitro plantlets of the three species were successfully acclimatized at $93 \%$ to $100 \%$ (Table 1).

Given these successful results, embryo culture of several other species of the genus Rosa was attempted. Many species were successfully germinated in vitro, acclimatized, and transferred into the rose garden (Table 2). Germination percentage and acclimatization success varied from one species to another, but the very small quantity of seeds received (sometimes <10) from the various botanical institutions made any statistical analyses of these percentages unreliable. Furthermore, some seeds could not be used because their embryos had aborted or been replaced by insects. The small quantity of seeds available for each species also made it inadvisable to soften the seedcoat by chemical or enzyme treatments as previously reported (Skirvin et al., 1990; Yambe and Takeno, 1992). As the hardness of the achenes was not the same for all species, several more achenes than had been provided would have been needed to optimize these treatments for each species. Mechanical excision was thus the most appropriate way to isolate the embryos from the achenes. However, good technical skills and patience are needed for species having achenes with a very hard pericarp.

For all species tested, good shoot development was obtained on germination medium, but root apices became necrotic after a few weeks in culture. However, it was possible to acclimatize all species by transferring the plantlets into soil after 3 to 4 weeks of culture.

Thus, we were able, from a very limited number of seeds, to use embryo culture to overcome seed dormancy and to obtain several species of the genus Rosa that could not be germinated by conventional procedures. Embryo culture resulted in an increase of $29 \%$ (from 108 to 139) of the number of species of the genus Rosa in the Montreal Botanical Garden rose collection. Since rose seeds are

Table 1. In vivo and in vitro germination and acclimatization of three Rosa species.

\begin{tabular}{lcccc}
\hline \hline Species of & $\begin{array}{l}\text { In vivo seed } \\
\text { Rosa }\end{array}$ & $\begin{array}{c}\text { In vitro seed } \\
\text { germination }\end{array}$ & $\begin{array}{c}\text { In vitro } \\
\text { embryo } \\
\text { germination }\end{array}$ & Acclimatization $^{2}$ \\
\hline nitida & $0 / 45$ & $0 / 15$ & $30 / 30$ & $14 / 15$ \\
& $(0 \%)$ & $(0 \%)$ & $(100 \%)$ & $(93 \%)$ \\
acicularis & $0 / 45$ & $0 / 15$ & $28 / 30$ & $15 / 15$ \\
& $(0 \%)$ & $(0 \%)$ & $(93 \%)$ & $(100 \%)$ \\
carolina & $0 / 45$ & $0 / 15$ & $18 / 30$ & $15 / 15$ \\
& $(0 \%)$ & $(0 \%)$ & $(60 \%)$ & $(100 \%)$ \\
\hline
\end{tabular}

${ }^{\mathrm{z}}$ Acclimatization success for 15 germinated embryos (see Materials and Methods for details). 
Table 2. Species of the genus Rosa obtained through in vitro embryo culture.

\begin{tabular}{|c|c|c|}
\hline Species & $\begin{array}{c}\text { Source of seeds } \\
\text { (botanical institution) }\end{array}$ & $\begin{array}{c}\text { Geographical } \\
\text { distribution }\end{array}$ \\
\hline R. serafinii Viv. & $\begin{array}{l}\text { Germany } \\
\text { (Botanisher Garten } \\
\text { Technische Universität, Dresden) }\end{array}$ & Mediterranean region \\
\hline R. marretii Lév. & $\begin{array}{l}\text { Poland } \\
\text { (Hortus Plantarum Medicinarum } \\
\text { Acad. Wroclaw) }\end{array}$ & Russia \\
\hline $\begin{array}{l}\text { R. vosagiaca } \\
\text { Desport. }\end{array}$ & $\begin{array}{l}\text { Switzerland } \\
\text { (Conservatoire et Jardin } \\
\text { Botaniques, Chambésy, Geneva) }\end{array}$ & Northern Europe \\
\hline $\begin{array}{l}\text { R. heckeliana } \\
\text { Tratt. }\end{array}$ & $\begin{array}{l}\text { Tczechoslovakia } \\
\text { (Arboretum Novy Dvur, Steborice) }\end{array}$ & Southern Europe \\
\hline R. nitida Willd. & $\begin{array}{l}\text { Belgium } \\
\text { (Hortus Botanicus Antverpiensis, } \\
\text { Antwerpen) }\end{array}$ & USA \\
\hline R. sempervirens L. & $\begin{array}{l}\text { Italy } \\
\text { (Dipartemento di Biologia } \\
\text { Ambientale, Orto Botanico- } \\
\text { Università di Siena, Siena) }\end{array}$ & $\begin{array}{r}\text { Southern Europe, } \\
\text { northern Africa }\end{array}$ \\
\hline R. nitidula Bess. & $\begin{array}{l}\text { Italy } \\
\quad \text { (as above) }\end{array}$ & Europe \\
\hline $\begin{array}{l}\text { R. luciae Franch. } \\
\text { \& Rochebr. }\end{array}$ & $\begin{array}{l}\text { Japan } \\
\text { (Ofuna Botanical Garden, } \\
\text { Kanagawa-Ken) }\end{array}$ & $\begin{array}{l}\text { East-Asia, } \\
\text { Japan }\end{array}$ \\
\hline R. zalana Wiesb. & $\begin{array}{l}\text { Hungary } \\
\quad \text { (Hortus Botanicus } \\
\text { Soroksarensis, Budapest) }\end{array}$ & Europe, Austria \\
\hline $\begin{array}{l}R \text {. orientalis } \\
\text { Dupont. ex Ser. }\end{array}$ & $\begin{array}{l}\text { Hungary } \\
\text { (Hortus Botanicus, Vacratot) }\end{array}$ & Greece, Albania \\
\hline $\begin{array}{l}\text { R. achburensis } \\
\text { Chrshan. }\end{array}$ & $\begin{array}{l}\text { Hungary } \\
\quad(\text { as above })\end{array}$ & Central Asia \\
\hline $\begin{array}{l}\text { R. montana } \\
\text { Chaix. }\end{array}$ & $\begin{array}{l}\text { France } \\
\text { (Conservatoire National des Plantes, } \\
\text { Milly-La-Forêt) }\end{array}$ & $\begin{array}{l}\text { Central and southern } \\
\text { Europe }\end{array}$ \\
\hline R. pouzinii Tratt. & $\begin{array}{l}\text { Spain } \\
\text { (Real Jardín Botanico-CSIC, Madrid) }\end{array}$ & Mediterranean region \\
\hline R. stylosa Desv. & $\begin{array}{l}\text { Spain } \\
\quad \text { (as above) }\end{array}$ & Western Europe \\
\hline R. stellata Woot. & $\begin{array}{l}\text { Spain } \\
\text { (as above) }\end{array}$ & USA \\
\hline $\begin{array}{l}\text { R. longicuspis } \\
\text { Bertol. }\end{array}$ & $\begin{array}{l}\text { China } \\
\text { (Hortus Botanicus, Inst. Botanici } \\
\text { Kunminensis, Kunming) }\end{array}$ & China \\
\hline $\begin{array}{l}\text { R. ×odorata } \\
\text { (Andr.) Sweet. }\end{array}$ & $\begin{array}{l}\text { China } \\
\text { (as above) }\end{array}$ & China \\
\hline R. banksiae Ait. & $\begin{array}{l}\text { China } \\
\quad \text { (as above) }\end{array}$ & China \\
\hline $\begin{array}{l}R \text {. gigantea } \\
\text { Coll. ex Crép. }\end{array}$ & $\begin{array}{l}\text { China } \\
\text { (as above) }\end{array}$ & China \\
\hline $\begin{array}{l}\text { R. maracandica } \\
\text { Bge. }\end{array}$ & $\begin{array}{l}\text { USA } \\
\text { (Joseph Halda Seeds, Englewood, } \\
\text { Colo.) }\end{array}$ & Tadjikistan \\
\hline R. ecae Aitchis. & $\begin{array}{l}\text { USA } \\
\text { (The Botanical Garden of } \\
\text { Smith College, Northhampton, } \\
\text { Mass.) }\end{array}$ & Afghanistan \\
\hline
\end{tabular}

difficult to germinate under conventional methods, it took more than 20 years to obtain the first 108 species. However, it took only 1 year to obtain 31 new species through in vitro embryo culture.

\section{Literature Cited}

Asen, S. 1948. Embryo culture of rose seeds. Amer. Rose Annu. 33:151-153.

Collins, G.B. and J.W. Grosser. 1984. Culture of embryos, p. 241-257. In: I.K. Vasil (ed.). Cell culture and somatic cell genetics of plants. vol. 1. Laboratory procedures and their applications. Academic, Orlando, Fla.

Hu, C. and P. Wang. 1986. Embryo culture: Technique and applications, p. 43-96. In: D.R. Evans, W.R. Sharp, and P.V. Ammirato (eds.). Handbook of plant cell culture. vol. 4. Techniques and applications. MacMillan, New York.

Lammerts, W.E. 1946. Use of embryo culture in rose breeding. Plants \& Gardens 2:111.

Marchant, R., J.B. Power, M.R. Davey, and J. Chartier-Hollis. 1994. Embryo rescue, for the production of $F_{1}$ hybrids, in English rose. Euphytica 74:187-193.

Murashige, T. and F. Skoog. 1962. A revised medium for rapid growth and bioassays with tobacco tissue cultures. Physiol. Plant. 15:473497.

Skirvin, R.M., M.C. Chu, and H.J. Young. 1990. Rose, p. 716-743. In: P.V. Ammirato, D.R. Evans, W.R. Sharp, and Y.P.S. Bajaj (eds.). Handbook of plant cell culture. vol. 5. Ornamental species. McGraw-Hill, New York.

Yambe, Y. and K. Takeno. 1992. Improvement of rose achene germination by treatment with macerating enzymes. HortScience 27:1018-1020. 